\title{
Antihyperlipidemic and hypolipidemic properties of Tacca leontopetaloides (L.) Kuntze (Dioscoreales: Dioscoreaceae) tuber's aqueous extracts in the rats
}

\author{
Doubla Sali Aïssatou ${ }^{1}$, Josiane Thérèse Ngatchic Metsagang, ${ }^{2}$, , Celestin \\ Dongmo Sokeng ${ }^{1}$ and Nicolas Yanou Njintang ${ }^{1}$
}

${ }^{1}$ Department of Biological Sciences, Faculty of Sciences, Ngaoundere University, P.O. Box 454, Ngaoundere, Cameroon.

${ }^{2}$ Department of Food Science and Nutrition, National School of Agro-Industrial Science, P.O. Box 455 Ngaoundere, Cameroon.*Email: josianetheresa@yahoo.fr.

\begin{abstract}
Tubers of Tacca leontopetaloides (L.) Kuntze (Dioscoreales: Dioscoreaceae) play an important role in food substitution during the periods of food shortage in occidental and central Africa. It is also used in traditional medicine for the treatment of the diarrhea, dysentery, stomach evil, viral hepatitis and the infection of guinea worn. This study attempted to evaluate the antihyperlipidemic and hypolipidemic properties of aqueous extracts of the tubers of $T$. leontopetaloides in rats. For this experimentation, two tests were done: antihyperlipidemic and hypolipidemic tests. Hyperlipidemia was induced in rats with High Fat Diet containing $300 \mathrm{~g}$ of egg yolk, $2 \mathrm{~g}$ of cholesterol, $250 \mathrm{~g}$ of coconut oil and $50 \mathrm{~g}$ of soya oil. The group of rats on which the antihyperlipidemic test was done was fed with High Fat Diet and supplemented with T. leontopetaloides aqueous extract at $27.34 \mathrm{mg} / \mathrm{kg}$, and 54.68 $\mathrm{mg} / \mathrm{kg}$; after 21 days of experimentation, the different groups of rats were sacrificed. The lipid profile and some biochemical parameters were evaluated. Organs like kidneys, liver and stomach were taken for histopathological evaluation. For the hypolipidemic test, after three weeks of induction of hyperlipidemia, the diet was changed to normal diet and aqueous extract of tubers was given to rats during 21 days at doses of $3.41 \mathrm{mg} / \mathrm{kg}$ and $13.67 \mathrm{mg} / \mathrm{kg}$. The animals were sacrificed after 21 days of experimentation. The lipid profile, some biochemical parameters and histopathology of organs were evaluated. The antihyperlipidemic and hypolipidemic tests of aqueous extract of the tubers of $T$. leontopetaloides induced reduction in total cholesterol, triglyceride, LDL-cholesterol and an increase in HDL-cholesterol significantly $(\mathrm{p}<0.05)$; decreasing activities of ALAT and ASAT enzymes, levels of creatinin remained no changed. Histopathological study revealed that extracts did not repair the destructions of liver cells and glomerules of kidneys caused by High Fat Diet. Aqueous extract of tubers of T. leontopetaloides exhibits antihyperlipidemic and hypolipidemic activities; hence it could be important in the management of cardiovascular diseases.
\end{abstract}

Received

February 23, 2017

Accepted

May 30, 2017

Released

June 30, 2017

Open Acess

Full Text Article

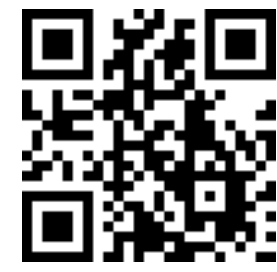

ORCID

(ㄷ) 0000-0002-0775-2198 Doubla Sali Aïssatou

(1) 0000-0002-5385-5518 Josiane Thérèse Ngatchic Metsagang

(1) 0000-0003-3713-059X Celestin Dongmo Sokeng

(b) 0000-0002-8949-7150 Nicolas Yanou Njintang 
Key words: Tacca leontopetaloides, antihyperlipidemia,
hypolipidemia, saponins.

\section{Introduction}

Hypercholesterolemia and hypertriglyceridemia are two major risk factors of cardiovascular diseases. They accelerate the development of coronary artery diseases and the progression of atherosclerosis (Ballantyne, 2007; Hamlat et al., 2008). High levels of low-density lipoprotein (LDL) accumulate in the extracellular and sub-endothelial space of arteries are highly atherogenic and toxic to vascular cells there by leading to atherosclerosis, hypertension, diabetes, functional depression in some organs (Suresh, 2001; Saghir et al., 2012). Tacca leontopetaloides is a wild plant belonging to the family of Taccaceae. It found in the tropical mediums, particularly in Occidental and Central Africa (Kay, 1987). The tubers of $T$. leontopetaloides have an important energetic value and play a crucial role in food substitution during the periods of food shortage in Africa (Kay, 1987; Garine, 2002). It is used in traditional medicine for the treatment of the diarrhea, dysentery and evils of stomach, viral hepatitis and the infection of Guinea worm (Kay, 1987; Garine, 2002). Studies of Ndouyang et al. (2009) showed that the tubers of T. leontopetaloides were rich in saponins (10.78\%). Several studies have shown hypolipidemia properties of saponins (Francis et al., 2002; Reynolds et al., 2006; Afrose et al., 2010). In spite of the fact that $T$. leontopetaloides tubers content saponins, no work has been interest on their effect on lipidemia.

Thus this study aim to evaluate the antihyperlipidemic and hypolipidemic properties of aqueous extracts of tubers of T. leontopetaloides.

\section{Materials and methods}

\section{the extract \\ Plant material and preparation of}

The tubers of $T$. leontopetaloides were collected in the locality of KarnaManga in the Adamaoua Region of Cameroon and were transported at the laboratory of Biophysics, Food Biochemistry and Nutrition of Ngaoundere University. The tubers were washed and rinsed with tap water.Thereafter, the tubers were peeled and sliced (sections of $7 \mathrm{~mm}$ Ø) using a chips slicer (Potato-chipper), $300 \mathrm{~g}$ of the sliced tubers were crushed with $3 \mathrm{~L}$ of distilled water using Moulinex (model Microton MB 550, Kinematica AG, Switzerland). Lastly, the crushed tubers was centrifuged at 4,000 tours/min during $20 \mathrm{~min}$, at $25^{\circ} \mathrm{C}$. The supernatant obtained was centrifuged again under the same conditions as previously described and the second supernatant constitutes aqueous extract.

\section{Chemical determination}

composition

Total phenol content of extract was determined as gallic acid equivalents according to the method described by Makkar et al. (1993) with some modifications. After extraction with $70 \%$ $(\mathrm{v} / \mathrm{v})$ methanol, in the same extract, total tannin content was determined by the precipitation method using polyvinylpyrrolidone (PVPP) as described by Makkar et al. (1993) with some modifications. PVPP in extract binds to tannins and make them inert. Briefly in $100 \mathrm{mg}$ PVPP, $1.0 \mathrm{~mL}$ of distilled water and $1.0 \mathrm{~mL}$ of sample extract were added. 
The blend was vortexed and kept at $4{ }^{\circ} \mathrm{C}$ for 15 min, vortexed once more and centrifuged at 3,000 trs/min for $10 \mathrm{~min}$ at $25{ }^{\circ} \mathrm{C}$. The supernatant composed of only simple phenolics other than tannins were collected. The phenolics content of the supernatant were determined as mentioned above and the content of non-tannin phenolics expressed. The tannin content of the sample was calculated as difference between total phenolics and non-tannin phenolics. The flavonoids were determined by the method describe by Adom et al. (2003). A volume of $0.1 \mathrm{~mL}$ of methalonic extract was introduced in solution prepared with 5\% sodium nitrate and $10 \%$ hexahydrated aluminium chlorite $\mathrm{ACL}_{3} 6 \mathrm{H}_{2} \mathrm{O}$. The $\mathrm{DO}$ was read at $510 \mathrm{~nm}$.

Saponins were evaluated according to the method of Hiai et al. (1976) with some modifications. $5 \mathrm{~mL}$ of aqueous extract of tubers were added to $5 \mathrm{~mL}$ of methanol (80\%). The mixture was homogenized and centrifuged at 3000 trs $/ \mathrm{min}$, for $10 \mathrm{~min}$ at $25^{\circ} \mathrm{C}$. The supernatant was recovered and evaporated at $50{ }^{\circ} \mathrm{C}$ in rotary evaporator until evaporation of methanol. To $0.1 \mathrm{~mL}$ of supernatant obtained, $0.25 \mathrm{~mL}$ of methanol (80\%) were added, $0.25 \mathrm{~mL}$ of vanillin (8\%) and $2.5 \mathrm{~mL}$ of sulphuric acid (72\%) were added slowly on the internal wall of the tube. The content of the tube was homogenized carried at $60{ }^{\circ} \mathrm{C}$ in the bainmarie. After 10 min of incubation, the tubes were cooled in tap water during 3-4 min, and read at $544 \mathrm{~nm}$ against white tube.

The alkaloid was determined according to Harborne (1991) methods with some modifications. A volume $\boldsymbol{v}$ of $20 \mathrm{~mL}$ of aqueous extract was centrifuged and filtered, to the aqueous filtrate; ammonia (40\%) solution was added until obtain $\mathrm{pH}$ $8-9$. Then this volume was extracted with $20 \mathrm{~mL}$ of chloroform and the two phases were separated using a decant ampoule. Thus the chloroform phase obtained was filtered in a becher and the weight was taken $\left(\mathrm{M}_{0}\right)$. The bechers containing the samples were left in the drying oven $103^{\circ} \mathrm{C}$ to enable chloroform evaporation. Then the dry extract was weighed $\left(\mathrm{M}_{1}\right)$. The alkaloid content (MA) was reported to the volume $v$ of aqueous extract having been treated. The alkaloid content was calculated by the following formula:

$$
M A=\frac{M_{1}-M_{0}}{v}(\mathrm{mg} / \mathrm{mL})
$$

\section{Animal experimentation and induction of hyperlipidemia}

Male adult Wistar albinos rats (200250 g) were obtained from the animal house of National School of Agro-Industrial Sciences of the University of Ngaoundere. The animals were used for both tests, antihyperlipidemic and hypolipidemic. Hyperlipidemia was induced by High Fat Diet (HFD) containing $300 \mathrm{~g}$ of egg yolk, 2 $\mathrm{g}$ of cholesterol, $250 \mathrm{~g}$ of coconut oil and $50 \mathrm{~g}$ of soya oil, as described by Hamlat et al. (2008) with some modifications. Table 1 shows the different formulations.

\section{Antihyperlipidemic test}

Thirty Wistar albinos' male rats weighing 200-250 g rats were randomly divided into 5 groups of 6 rats each. The rats were housed in cages in a room where the temperature was $37^{\circ} \mathrm{C}$ and $12 \mathrm{~h}$ light and dark cycles were maintained and water was given ad libitum. The first group fed with HFD (negative control, GI), the second group fed with HFD and atorvastatin at 10 $\mathrm{mg} / \mathrm{kg}$ (positive control, GII), the third group fed with HFD and aqueous extract of tuber of $T$. leontopetaloides at the dose of $27.34 \mathrm{mg} / \mathrm{kg}$ (GIII), the fourth group was fed with HFD and aqueous extract of tuber of T. leontopetaloides at the dose of 54.68 $\mathrm{mg} / \mathrm{kg}$ (GIV) and the five group was fed with standard diet (normal control, GV). The animals were weighed each week, the quantity of feed intake was obtained by subtracting the remaining feed from the quantity administered the previous days. Feces were collected daily for the evaluation of the excreted lipids. After three weeks, the animals were sacrificed by anesthesia using diethyl ether, and the blood samples were collected from the jugular vein. The liver, kidney and stomach were promptly removed and fixed in formaldehyde solution for histopathological 
examination. The blood was collected in the dry tubes and allowed to stand for $30 \mathrm{~min}$, then centrifuged at $3000 \mathrm{trs} / \mathrm{min}$ for $15 \mathrm{~min}$, serum samples obtained were collected in dry tubes, and kept at $-20^{\circ} \mathrm{C}$ for biochemical estimation.

Table 1. Diet composition for hyperlipidemia induction.

\begin{tabular}{llcccc}
\hline \multirow{2}{*}{ Food components } & \multicolumn{2}{c}{ Normal diet } & \multicolumn{2}{c}{ High fat diet } \\
\cline { 3 - 6 } & Fish powders & $\begin{array}{c}\text { Incorporation } \\
\mathbf{( g / k g )}\end{array}$ & Energy(kcal) & $\begin{array}{c}\text { Incorporation } \\
\text { (g/kg) }\end{array}$ & Energy (kcal) \\
\hline \multirow{2}{*}{ Protein } & 200 & 800 & 140 & 560 \\
\multirow{4}{*}{ Lipidids } & Starch & 590 & 2,360 & 283 & 1,132 \\
& Sucrose & 50 & 200 & 50 & 200 \\
& Coconut oi & - & - & 250 & 2,250 \\
& Egg yolk & - & - & 300 & 2,700 \\
\multirow{3}{*}{ Others } & Soya oil & 50 & 450 & 50 & 450 \\
& Cholesterol & - & - & 2 & 18 \\
& Cellulose & 50 & - & 50 & - \\
& Minerals & 10 & - & - & - \\
\hline Total & Vitamins & 50 & - & 1000 & 7,310 \\
\hline
\end{tabular}

\section{Assessment of lipid profil, transaminase and creatinin}

Levels of total cholesterol (TC), triglycerides (TG) and high density lipoprotein cholesterol (HDL-C) were evaluated using enzymatic kits (HUMAN kits) according to procedure described by Richmond (1973) and Glick et al. (1986). Low density lipoprotein cholesterol and Very low density lipoprotein (LDL-C, VLDL-C) were calculated according to Friedewald et al. (1972) formula: $\operatorname{LDL}-\mathrm{C}\left(\frac{\mathrm{mg}}{\mathrm{dz}}\right)=$ (TC-(TG/5+HDL-C); $V L D L-C\left(\frac{m g}{d L}\right)=\frac{T G}{5}$. Alanine aminotransferase (ALAT) and aspartate aminotransferase (ASAT) were determined according to the method of Reitman and Frankel (1957) while the level of was determined creatinin according to the Method of Henry (1974).

\section{Experimental protocol for hypolipidemic test}

During the antihyperlipidemic test, thirty Wistar albinos male rats weighing between 200-250 g were divided into 5 groups of 6 rats each. They were also fed with high fat diet for 21 days to induce hyperlipidemia, after induction these rats were used for hypolipidemic test. The rats were fed with the standard diet and the aqueous extract of tubers during 21 days. The extract was given orally a day. Group I
(GI) received standard diet and aqueous extract of $T$. leontopetaloides at the dose of $3.41 \mathrm{mg} / \mathrm{kg}$. Group II (GII) received standard diet and aqueous extract of $T$. leontopetaloides at the dose of 13.67 $\mathrm{mg} / \mathrm{kg}$. Group III (GIII) received standard diet and atorvastatin (positive control) at the dose of $10 \mathrm{mg} / \mathrm{kg}$. Group IV (GIV) received standard diet (negative control). The control group (Group V) (GV) is the group which during the induction of hyperlipidemia and was fed with standard diet. After 21 days of experimentation, the animals were sacrificed, and the different parameters were evaluated as describe in antihyperlipidemic test.

\section{Analysis of faecal lipid}

Feces were collected daily for the evaluation of the excreted lipids. The fecal matter was then dried and crushed with the porcelain mortar into fine powder. The total lipids were extracted using the Soxhlet apparatus, according to the Russian method described by Bourely (1982).

\section{Histopathological examination}

Histopathological examinations were done on kidneys, livers and stomach. Organs were fixed in formaldehyde (10\%) and the tissues subsequently dehydrated in 
upgraded concentrations of ethanol $(10 \%-$ $90 \%$ ), cleaned in xylene, impregnated and embedded in paraffin. Sections of $5 \mathrm{~mL}$ were cut using. Microtome stained with hematoxylin and eosin stains. Light microscopic examination of multiple tissue sections from each organ in all groups was performed and images of the typical histological profile were examined.

\section{Statistical analysis}

The statistical analysis of the results was made using analysis variance (ANOVA) followed by multiple comparison Test of Kruskal-Wallis, using the statistical software Statgraphics Centurion XV.II. The values of $\mathrm{P}<0.05$ were considered as statistically significant.

\section{ResultsChemical composition of $T$.} leontopetaloides aqueous extract

Phytoconstituents like polyphenols especially flavonoids (Adom et al., 2003) and saponins (Francis et al., 2003) are known to have ability to reduce lipidemia. Phytochemical analysis of aqueous extract of the tubers of $T$. leontopetaloides showed different phytoconstituents likes polyphenols $(0.60 \pm 0.01 \mathrm{mg} / \mathrm{mL})$, alkaloids $(0.83 \pm 0.08 \mathrm{mg} / \mathrm{mL})$ and saponins $(0.78 \pm$ $0.06 \mathrm{mg} / \mathrm{mL}$ ).

\section{Antihyperlipidemic proprieties of T. leontopetaloides \\ Effects of the aqueous extract of} the tubers of $T$. leontopetaloides on the body weight, the food intake and lipid profile of $\mathbf{t}$ rats. Table 2 shows that there is a significant difference between the food intakes of all groups of rats. Concerning weight gain/weight loss there is significant difference $\mathrm{p}<0.05$ between the groups that received extracts (GIII $27.34 \mathrm{mg} / \mathrm{kg}$ and GIV $54.68 \mathrm{mg} / \mathrm{kg}$ ) compared to the groups that did not received (GI and GV). The negative sign means that the rats lost weight, it is the case with GIII and GIV. Weight loss observed in these groups will be the consequence of their low food intake which is significantly low compared to that of the other groups.

Concerning the lipid profile, results showed that atorvastatin and aqueous extract of tubers reduced lipid parameters. In fact, levels of TC, TG and LDL-C of rats belonging to the negative group (GI) are high than that of the groups received taken aqueous extract of the tuber of $T$. leontopetaloides $(27.34 \mathrm{mg} / \mathrm{kg} \mathrm{G}$ III, 54.68 $\mathrm{mg} / \mathrm{kg}$ GIV) and the group that received atorvastatin group (GII). The contrary was obtained with HDL-C. Results on fecal lipid shows that group GII, GIII and GIV excreted more lipids than the negative group GI. These results showed that aqueous extracts of tubers inhibit absorption of lipids.

Effects of the aqueous extract of the tubers of $T$. leontopetaloides on creatinin, ALAT, ASAT levels and organs to body weight ratios of rats. Compared to the normal control (GV), Table 3 shows that high content fat diet had significantly $(\mathrm{P}<0.05)$ increased the serum levels of creatinin of rats (GI). The activities of ALAT and ASAT enzymes were increased in groups that received extract (GIII, GIV) compared to the normal control (GV). The consumption of hyperlipidemic diet induced an increase of abdominal fat (3.32\%) in GI, in GIII and GIV the increased was (2.67\%) and (2.36\%), respectively. The liver to weight body ratios of all treated groups where no changed as compared to the control GV. The body weight ratio of the heart of GIII was less increased compared to the control $\mathrm{GV}$. The stomach body ratio was increased for GIII and GIV as compared to the normal control GV, the reverse observation was noticed with testis body weight ratio. 
Table 2. Effect of the aqueous extract of the tubers of $T$. leontopetaloides on weight, food intake and lipid profile of the rats.

\begin{tabular}{lccccc}
\hline Parameter & GI & GII & GIII & GIV & GV \\
\hline W.G/W.L (g) & $29.9 \pm 0.6^{\mathrm{a}}$ & $6.6 \pm 0.0^{\mathrm{b}}$ & $-6.5 \pm 0.0^{\mathrm{c}}$ & $-28.7 \pm 0.0^{\mathrm{d}}$ & $19.0 \pm 0.0^{\mathrm{e}}$ \\
F.I (g) & $216.9 \pm 13.1^{\mathrm{c}}$ & $240.1 \pm 1^{\mathrm{d}}$ & $138.9 \pm 19.3^{\mathrm{b}}$ & $125.9 \pm 16.1^{\mathrm{a}}$ & $292.6 \pm 18^{\mathrm{e}}$ \\
CT (mg/dL) & $94.0 \pm 14.6^{\mathrm{a}}$ & $47.4 \pm 0.7^{\mathrm{b}}$ & $65.1 \pm 0.30^{\mathrm{c}}$ & $10.6 \pm 0.30^{\mathrm{d}}$ & $78.8 \pm 0.6^{\mathrm{e}}$ \\
TG (mg/dL) & $80.65 \pm 2.1^{\mathrm{a}}$ & $11.0 \pm 0.1^{\mathrm{b}}$ & $77.45 \pm 4.2^{\mathrm{c}}$ & $156.05 \pm 11.8^{\mathrm{d}}$ & $75.3 \pm 2.04^{\mathrm{e}}$ \\
HDL-C & & & & \\
(mg/dL) & $0.52 \pm 0.04^{\mathrm{a}}$ & $10.7 \pm 0.14^{\mathrm{b}}$ & $41.2 \pm 0.59^{\mathrm{c}}$ & $37.8 \pm 0.33^{\mathrm{d}}$ & $32.0 \pm 0.42^{\mathrm{e}}$ \\
LDL-C & & & & \\
(mg/dL) & $90.15 \pm 25.1^{\mathrm{a}}$ & $10.96 \pm 5.21^{\mathrm{b}}$ & $86.83 \pm 31.8^{\mathrm{c}}$ & $62.78 \pm 3.3^{\mathrm{d}}$ & $85.5 \pm 1.2^{\mathrm{c}}$ \\
VLDL (mg/dL) & $16.13 \pm 0.41^{\mathrm{a}}$ & $22.0 \pm 0.03^{\mathrm{b}}$ & $15.49 \pm 0.84^{\mathrm{ae}}$ & $22.45 \pm 0.77^{\mathrm{b}}$ & $13.51 \pm 0.85^{\mathrm{e}}$ \\
F.L (\%) & $6.59 \pm 1.98^{\mathrm{a}}$ & $18.53 \pm 0.2^{\mathrm{b}}$ & $17.96 \pm 1.3^{\mathrm{b}}$ & $17.96 \pm 1.3^{\mathrm{b}}$ & $\mathrm{nd}^{\mathrm{b}}$ \\
\hline
\end{tabular}

GI: group receiving High Fat Diet (negative group); GII: group receiving High Fat Diet + Atorvastatin 10 mg/kg (positive group); GIII: group receiving High Fat Diet + aqueous extract $27.34 \mathrm{mg} / \mathrm{kg}$; G IV: group receiving High Fat Diet + the aqueous extract $54.68 \mathrm{mg} / \mathrm{kg} ; \mathbf{G V}$ :group receiving Normal diet; W.G: weight gain of rats, W.L: weight lost, F.I: total food intake, TC: total cholesterol, TG: triglyceride, HDL: high density lipoprotein, LDL: low density lipoprotein,VLDL: very low density lipoprotein, FL: fecal lipid. nd: no determined. Values are expressed as mean \pm SD, $n=6$ in each group. Means followed by different letters $(\mathrm{a}-\mathrm{e})$ in the same line are significantly different $(\mathrm{p}<0.05)$.

Table 3. Effects of the aqueous extract of tubers of $T$. leontopetaloides on creatinin, ALAT, ASAT levels

\begin{tabular}{|c|c|c|c|c|c|}
\hline and & to & body & weight & ratios & rats \\
\hline Parameter & GI & GII & GIII & GIV & GV \\
\hline $\begin{array}{l}\text { Creatinin } \\
\text { (mg/dL) }\end{array}$ & $17.4 \pm 1.9^{\mathrm{b}}$ & $11.5 \pm 0.4^{\mathrm{a}}$ & $11.6 \pm 0.4^{\mathrm{a}}$ & $11.5 \pm 0.2^{\mathrm{a}}$ & $11.1 \pm 0.8^{\mathrm{a}}$ \\
\hline $\operatorname{ALAT}(\mathrm{UI} / \mathrm{L})$ & $40.6 \pm 8.4^{\mathrm{a}}$ & $53.1 \pm 4.1^{b}$ & $53.9 \pm 2.9^{b}$ & $53.15 \pm 4.5^{\mathrm{b}}$ & $45.0 \pm 0.5^{\mathrm{a}}$ \\
\hline ASAT (UI/L) & $36.5 \pm 5.0^{\mathrm{a}}$ & $44.0 \pm 0.1^{\mathrm{b}}$ & $44.0 \pm 0.7^{\mathrm{b}}$ & $44.1 \pm 0.5^{b}$ & $38.5 \pm 0.7^{\mathrm{ab}}$ \\
\hline A.F & $3.32 \pm 0.09^{c}$ & $2.23 \pm 0.11^{\mathrm{a}}$ & $2.67 \pm 0.05^{\mathrm{b}}$ & $2.36 \pm 0.19^{\mathrm{a}}$ & $2.09 \pm 0,28^{\mathrm{a}}$ \\
\hline Liver & $3.24 \pm 0.13^{b}$ & $2.95 \pm 0.07^{\mathrm{a}}$ & $2.54 \pm 0.14^{\mathrm{a}}$ & $2.54 \pm 0.11^{\mathrm{a}}$ & $2.92 \pm 0.23^{\mathrm{a}}$ \\
\hline Kidney & $0.54 \pm 0.01^{\mathrm{a}}$ & $0.59 \pm 0.01^{b}$ & $0.59 \pm 0.09^{b}$ & $0.59 \pm 0.01^{\mathrm{b}}$ & $0.56 \pm 0.04^{\mathrm{ab}}$ \\
\hline Heart & $0.32 \pm 0.01^{\mathrm{a}}$ & $0.35 \pm 0.01^{\mathrm{c}}$ & $0.33 \pm 0.05^{\mathrm{b}}$ & $0.35 \pm 0.01^{\mathrm{c}}$ & $0.31 \pm 0.02^{\mathrm{a}}$ \\
\hline Stomach & $0.65 \pm 0.02^{\mathrm{a}}$ & $0.71 \pm 0.01^{\mathrm{b}}$ & $0.77 \pm 0.09^{\mathrm{bc}}$ & $0.78 \pm 0.03^{\mathrm{bc}}$ & $0.65 \pm 0.01^{\mathrm{a}}$ \\
\hline Testis & $1.03 \pm 0.06^{\mathrm{b}}$ & $0.89 \pm 0.09^{\mathrm{a}}$ & $0.89 \pm 0.01^{\mathrm{a}}$ & $0.89 \pm 0.06^{\mathrm{a}}$ & $1.14 \pm 0.13^{\mathrm{C}}$ \\
\hline
\end{tabular}

GI: group receiving High Fat Diet (negative group); GII: group receiving High Fat Diet + Atorvastatin $10 \mathrm{mg} / \mathrm{kg}$ (positive group); GIII: group receiving High Fat Diet + the aqueous extract $27.34 \mathrm{mg} / \mathrm{kg}$; GIV: group receiving High Fat Diet + the aqueous extract 54.68 mg/kg; GV:group receiving Normal diet; ALAT: alanine aminotransferase; ASAT: aspartate aminotransferase. A.F: abdominal fat. Values are expressed as mean $\pm S D, n=6$ in each group. Means followed by different letters $(a-c)$ in the same line are significantly different $(\mathrm{p}<0.05)$.

\author{
Hypolipidemic properties of the \\ aqueous extract of tubers of $T$. \\ leontopetaloides \\ Effects of the aqueous extracts of \\ the tubers of $T$. leontopetaloides on \\ weight, food intake and lipid profile of \\ hyperlipidemic rats. Table 4 shows that \\ there was a significant difference $\mathrm{p}<0.05$ \\ between the groups threated (GII, GIII,
}

GIV), normal group ( $\mathrm{G} V$ ) and negative group (G I) about weight. Concerning food intake we noted that, there was a significant difference between all the groups. The negative sign of groups GII, GIII and GIV indicates that the animal lost weight during the treatment.Antihyperlipidemic test showed that high fat diet given for 21 days to rats caused a significantly $(\mathrm{p}<0.05)$ 
increased of serum triglycerides, LDLcholesterol, total cholesterol and decreased HDL-cholesterol levels. On the other hand, administration of aqueous extract of T. leontopetaloides to GIII, GIV and atorvastatin to GII for 21 days resulted in a significant $(\mathrm{p}<0.05)$ decrease in the total cholesterol, triglycerides, LDL-C and VLDL-C levels of the rats of these groups compared to control negative group GI. We have also noticed that administration of aqueous extract of $T$. leontopetaloides to GIII, GIV and atorvastatin to GII for 21 days resulted in a significant $(\mathrm{p}<0.05)$ increase in the serum HDL levels when compared with the negative control group (GI). Fecal lipid of group GIII and GIV of the rats taking extract and group GII taking atorvastatin are statistically equal, and significantly high than that of the negative control group GI.

Table 4. Effect of the aqueous extracts of $T$. leontopetaloides tubers on the weight gain and weight lost,

\begin{tabular}{|c|c|c|c|c|c|}
\hline food & intake & lipid & profil & \multicolumn{2}{|c|}{ hyperlipidemic } \\
\hline Parameter & GI & GII & GIII & GIV & GV \\
\hline W.G/W.L (g) & $19.0 \pm 0.0^{\mathrm{c}}$ & $-25 \pm 0.0^{\mathrm{b}}$ & $-29.91 \pm 0.67^{\mathrm{a}}$ & $-25.5 \pm 0.0^{b}$ & $19.01 \pm 0.1^{\mathrm{c}}$ \\
\hline F.I (g) & $250.0 \pm 0.0^{\mathrm{d}}$ & $118.8 \pm 0.0^{\mathrm{a}}$ & $141.0 \pm 0.0^{\mathrm{c}}$ & $126.7 \pm 0.0^{\mathrm{b}}$ & $292.5 \pm 1.8^{\mathrm{e}}$ \\
\hline $\mathrm{CT}(\mathrm{mg} / \mathrm{dL})$ & $99.8 \pm 3.7^{\mathrm{C}}$ & $78.5 \pm 0.8^{b}$ & $73.5 \pm 1.2^{\mathrm{a}}$ & $78.5 \pm 0.5^{\mathrm{b}}$ & $78.8 \pm 0.5^{\mathrm{b}}$ \\
\hline $\mathrm{TG}(\mathrm{mg} / \mathrm{dL})$ & $68.5 \pm 6.1^{\mathrm{b}}$ & $20.5 \pm 2.8^{\mathrm{a}}$ & $21.0 \pm 4.0^{\mathrm{a}}$ & $24.0 \pm 1.6^{\mathrm{a}}$ & $75.3 \pm 2.0^{\mathrm{c}}$ \\
\hline HDL-C (mg/dL) & $0.4 \pm 0.2^{\mathrm{a}}$ & $11 \pm 0.4^{\mathrm{b}}$ & $12 \pm 0.2^{\mathrm{b}}$ & $10 \pm 0.1^{\mathrm{b}}$ & $61.7 \pm 2.1^{\mathrm{c}}$ \\
\hline LDL-C (mg/dL) & $83.6 \pm 0.7^{\mathrm{d}}$ & $71.4 \pm 0.3^{c}$ & $63.6 \pm 0.3^{b}$ & $63.0 \pm 1.2^{\mathrm{b}}$ & $0.2 \pm 0.0^{\mathrm{a}}$ \\
\hline VLDL (mg/dL) & $78 \pm 0.86^{\mathrm{d}}$ & $41 \pm 0.5^{c}$ & $31.03 \pm 1.3^{\mathrm{b}}$ & $31.01 \pm 0.3^{\mathrm{b}}$ & $15.0 \pm 0.4^{\mathrm{a}}$ \\
\hline FL (\%) & $16.3 \pm 0.7^{\mathrm{a}}$ & $26.4 \pm 1.7^{\mathrm{b}}$ & $26.4 \pm 1.5^{\mathrm{b}}$ & $26.4 \pm 2.8^{\mathrm{b}}$ & \\
\hline
\end{tabular}

G I: group receiving High Fat Diet (negative group); G II: positive control group receiving Atorvastatin $(10 \mathrm{mg} / \mathrm{kg})$; G III: group receiving the aqueous tuber extract $(3.41 \mathrm{mg} / \mathrm{kg}) ; \mathbf{G I V}$ : group receiving the aqueous tuber extract (13.67 mg/kg); GV: Normal control; W.G: weight gain of rats, W.L: weight lost; F.I: food intake; FL: faecal lipid. Values are expressed as mean $\pm \mathrm{SD}, \mathrm{n}=6$ in each group. Means followed by different letters $(a-e)$ in the same line are significantly different $(p<0.05)$.

Effect of the aqueous extracts of T. leontopetaloides tubers on creatinin, ALAT, ASAT levels and organ to body weight of hyperlipidemic rats. The effect of the aqueous extract is presented in Table 5. Creatinin is often regarded as reliable markers of the kidney function and it remains no changed in the rats treated of GIII, GIV as compared to the normal GV. Administration of aqueous extract of $T$. leontopetaloides to GIII, GIV and atorvastatin to GII for 21 days resulted in a significant $(\mathrm{p}<0.05)$ decreased the activities of the liver enzymes (AST and ALT) in these groups of rats when compared with the normal GV. GI which received no drug showed significant $(p<0.05)$ increase of the activities of these enzymes (ASAT and ALT) compared to the normal GV.

Table 5. Effect of the aqueous extract of T. leontopetaloides tubers on creatinin, ALAT, ASAT levels and organ to body weight ratios of hyperlipidemic rats.
Organs to body weight ratios of rats of G III and GIV treated with aqueous extract of T. leontopetaloides are comparable to these of normal GV. In this study the abdominal fat to body ratio decreased in the treated groups GIII, GIV and atorvastatin GII compared to normal $\mathrm{GV}$, but it was significant $(\mathrm{p}<0.05)$ increased in GI which received no drug as compared to the normal GV. The liver, kidneys body ratios showed normal in the treated G III and GIV compared to that of the normal GV. In contrast the body ratio of heart did no varied significantly with hyperlipidemic diet and the aqueous extract in all the groups. Stomach ratios in GIII, GIV were higher compared to that of the normal $G \mathrm{~V}$, while the decreasing testis ratios were observed in these groups. 


\begin{tabular}{lccccc}
\hline Parameter & GI & GII & GIII & GIV & GV \\
\hline Creatinin (mg/dL) & $51.9 \pm 0.13^{\mathrm{a}}$ & $11.65 \pm 0.20^{\mathrm{b}}$ & $52.5 \pm 0.61^{\mathrm{a}}$ & $56.5 \pm 0.52^{\mathrm{a}}$ & $56.5 \pm 1.08^{\mathrm{a}}$ \\
ASAT (UI) & $16.2 \pm 0.26^{\mathrm{b}}$ & $28.3 \pm 0.17^{\mathrm{a}}$ & $16.87 \pm 42.13^{\mathrm{b}}$ & $16.5 \pm 0.61^{\mathrm{b}}$ & $38.5 \pm 0.69^{\mathrm{c}}$ \\
ALAT (UI) & $15 \pm 0.32^{\mathrm{a}}$ & $35.5 \pm 0.12^{\mathrm{b}}$ & $15.59 \pm 0.94^{\mathrm{a}}$ & $15.85 \pm 0.43^{\mathrm{a}}$ & $45 \pm 0.57^{\mathrm{c}}$ \\
\hline A.F & $6.92 \pm 0.50^{\mathrm{a}}$ & $9.15 \pm 0.75^{\mathrm{b}}$ & $6.18 \pm 0.60^{\mathrm{a}}$ & $6.74 \pm 0.60^{\mathrm{a}}$ & $6.02 \pm 2.37^{\mathrm{a}}$ \\
Liver & $2.82 \pm 0.10^{\mathrm{a}}$ & $2.69 \pm 0.15^{\mathrm{a}}$ & $2.79 \pm 0.11^{\mathrm{a}}$ & $2.63 \pm 0.39^{\mathrm{a}}$ & $2.90 \pm 0.24^{\mathrm{a}}$ \\
Kidneys & $0.55 \pm 0.02^{\mathrm{a}}$ & $0.55 \pm 0.02^{\mathrm{a}}$ & $0.53 \pm 0.03^{\mathrm{a}}$ & $0.50 \pm 0.06^{\mathrm{a}}$ & $0.56 \pm 0.04^{\mathrm{a}}$ \\
Heart & $0.30 \pm 0.02^{\mathrm{b}}$ & $0.28 \pm 0.01^{\mathrm{a}}$ & $0.30 \pm 0.02^{\mathrm{b}}$ & $0.37 \pm 0.03^{\mathrm{b}}$ & $0.31 \pm 0.02^{\mathrm{b}}$ \\
Stomach & $0.78 \pm 0.02^{\mathrm{b}}$ & $0.68 \pm 0.05^{\mathrm{a}}$ & $0.79 \pm 0.08^{\mathrm{b}}$ & $0.72 \pm 0.07^{\mathrm{b}}$ & $0.68 \pm 0.05^{\mathrm{a}}$ \\
Testis & $1.04 \pm 0.04^{\mathrm{b}}$ & $1.02 \pm 1.02^{\mathrm{b}}$ & $0.85 \pm 0.06^{\mathrm{a}}$ & $0.99 \pm 0.10^{\mathrm{ab}}$ & $1.12 \pm 0.09^{\mathrm{b}}$ \\
\hline
\end{tabular}

GI: group receiving High Fat Diet (negative group); GII: positive control group receiving Atorvastatin $(10 \mathrm{mg} / \mathrm{kg})$; GIII: group receiving the aqueous tuber extract $(3.41 \mathrm{mg} / \mathrm{kg}) ; \mathbf{G I V}$ : group receiving the aqueous tuber extract (13.67 $\mathrm{mg} / \mathrm{kg})$; GV: Normal diet; ALAT: alanine aminotransferase; ASAT: aspartate aminotransferase. A.F: abdominal fat. Values are expressed as mean $\pm \mathrm{SD}, \mathrm{n}=6$ in each group. Means followed by different letters $(a-c)$ in the same line are significantly) different $(p<0.05)$.

\section{Histopathological studies}

In antihyperlipidemic test, destruction of glomerules of kidneys of rats receiving HFD was observed (Figure 1, A1). Rats receiving $27.34 \mathrm{mg} / \mathrm{kg}$ and $54.68 \mathrm{mg} / \mathrm{kg}$ of aqueous extract of the tuber presented normal glomerules (Figure 1, A, A4, A5). Degeneration of hepatocytes in the groups receiving $27.34 \mathrm{mg} / \mathrm{kg}$ and 54.68 $\mathrm{mg} / \mathrm{kg}$ of aqueous extract of the tuber was noted (Figure 2, B4, B5) as compared to the control group (Figure 2, B1), and the stomach of rats that received aqueous extract of tubers showed no significant change in the cytoarchitecture (Figure 3, C4, C5).

In hypolipidemic test, glomerular destruction was observed at the level of the rats kidneys that received $3.41 \mathrm{mg} / \mathrm{kg}$ and $13.67 \mathrm{mg} / \mathrm{kg}$ of aqueous extract of the tuber (Figure 4, D4, D5) as compared to the control normal group. The histopathological of the rats treated with the aqueous extract of tubers showed a hepatocellular degenerative in the liver (Figure 5, E4, E5). No significant change in the cytoarchitecture of the stomach of rats treated with aqueous extract of tubers (Figure 6, F4, F5) was observed.
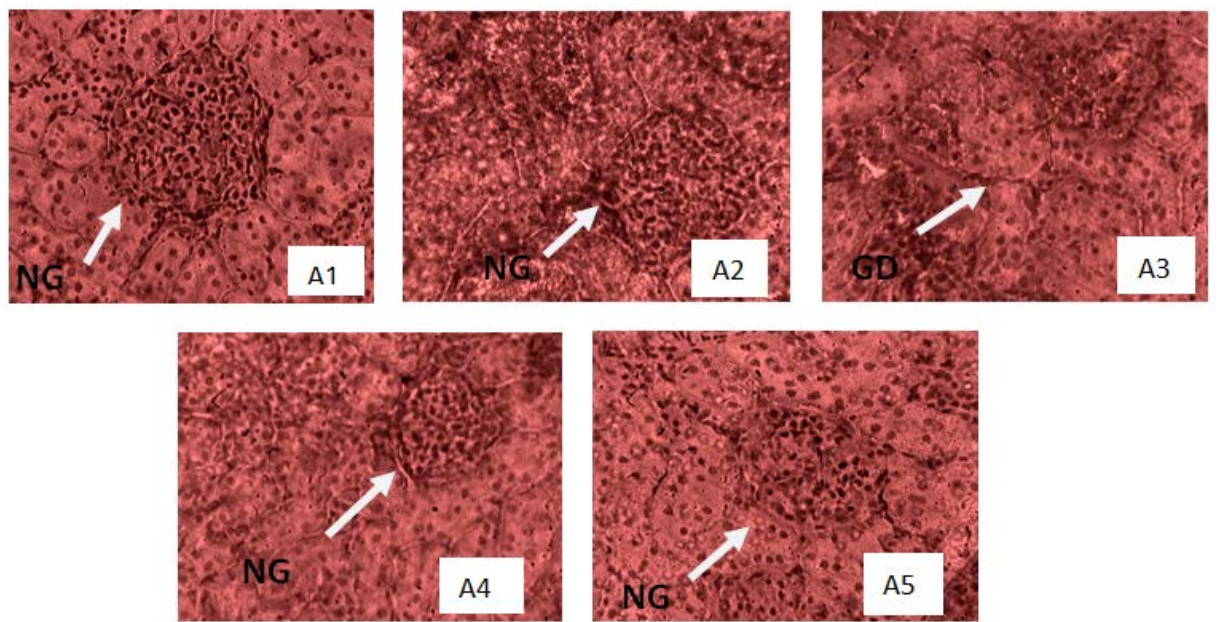

Figure 1. Histological section of kidney of rats of antihyperlipidemic test: (A1) normal diet, (A2) hyperlipidemic diet + Atorvastatine , (A3) hyperlipidemic diet, (A4) hyperlipidemic diet + aqueous extract $27.34 \mathrm{mg} / \mathrm{kg}$, (A5) hyperlipidemic diet + aqueous extract $54.68 \mathrm{mg} / \mathrm{kg}$. NG: normal glomerulus, GD: glomerular destruction (Magnification: 400×). 

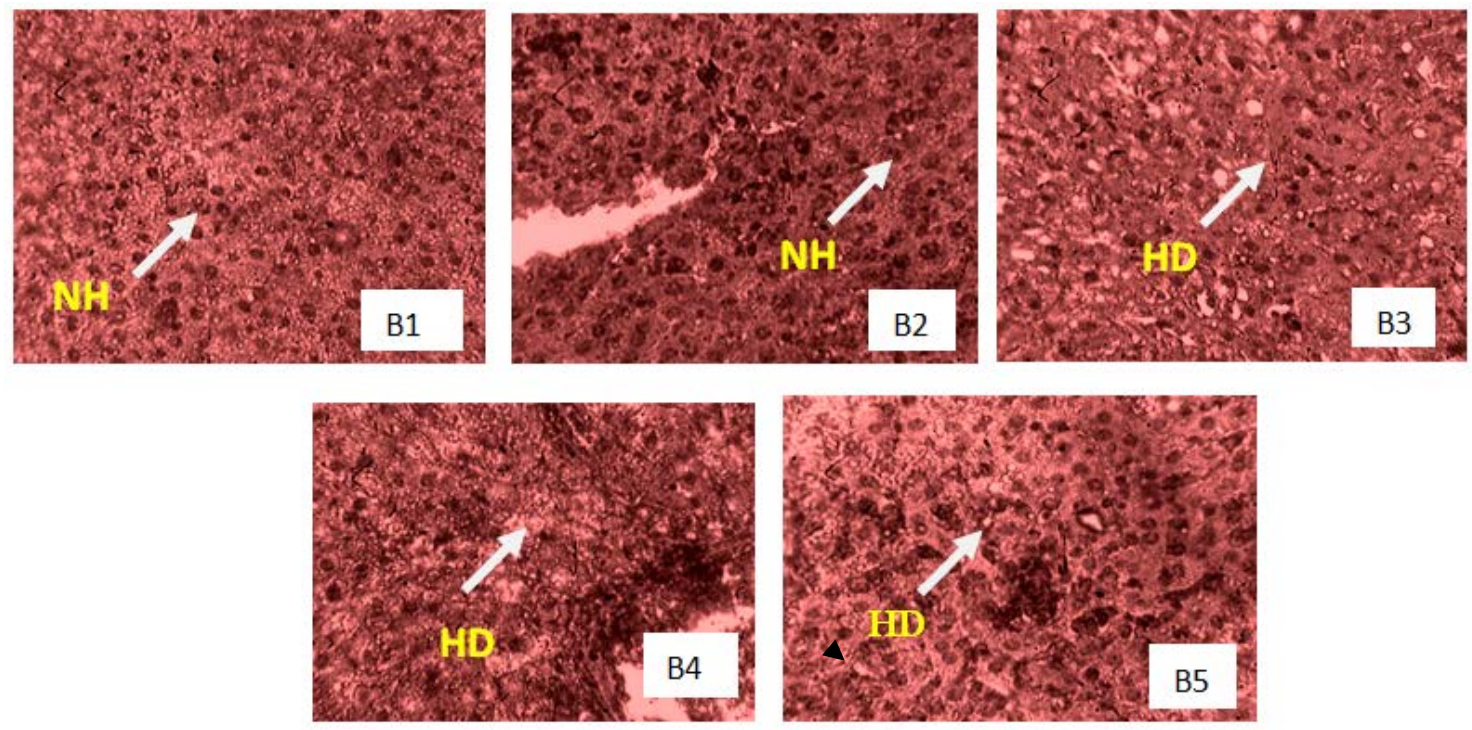

Figure 2. Histological section of livers of rats of antihyperlipidemic test: (B1) normal diet, (B2) hyperlipidemic diet + Atorvastatine, (B3) hyperlipidemic diet, (B4) hyperlipidemic diet + aqueous extract $27.34 \mathrm{mg} / \mathrm{kg}$, (B5) hyperlipidemic diet + aqueous extract $54.68 \mathrm{mg} / \mathrm{kg}$. NH: normal hepatocyte; HD: Hepatocyte degenerative. (Magnification: 400×).
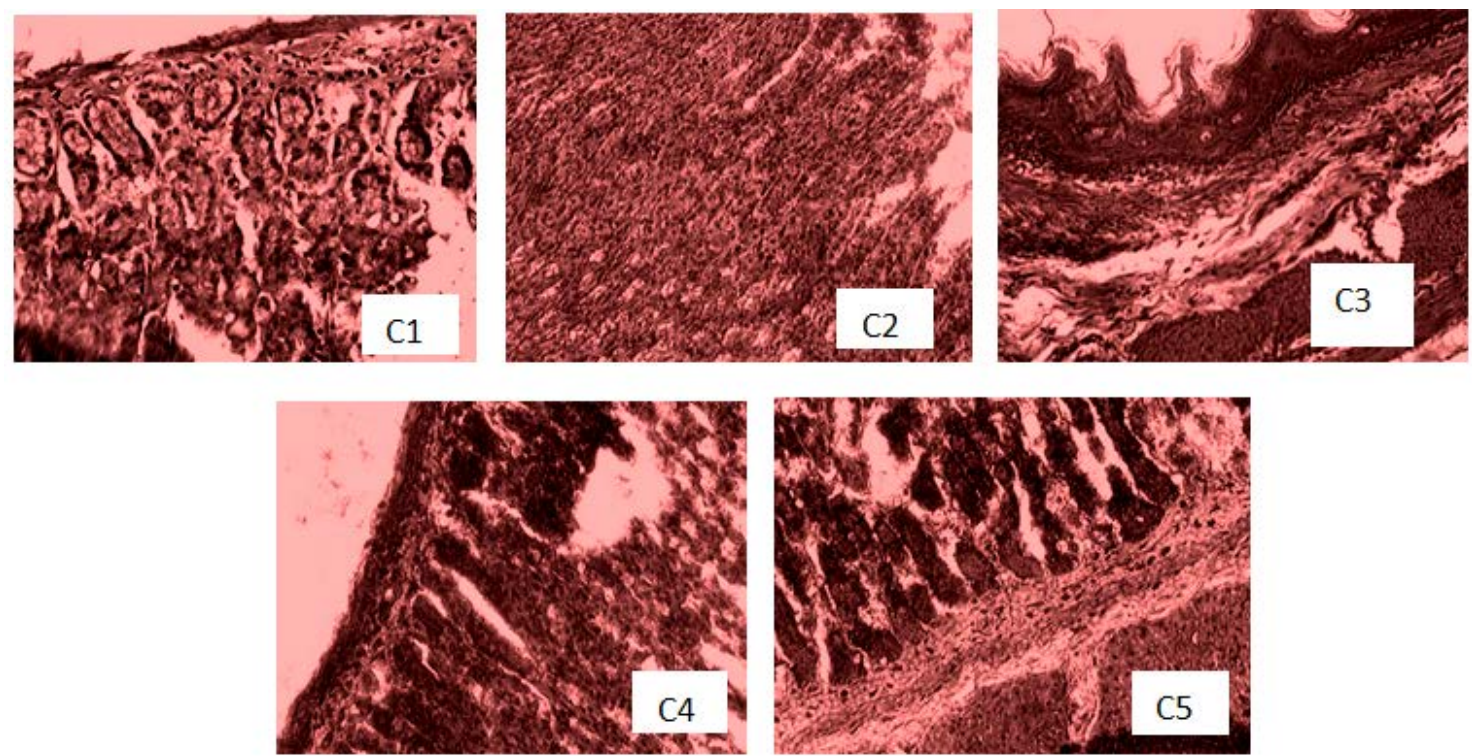

Figure 3. Histological section of stomachs of rats of antihyperlipidemic test: (C1) normal diet, (C2) hyperlipidemics diet + Atorvastatine, (C3) hyperlipidemics diet, (C4) hyperlipidemics diet + aqueous extract $27.34 \mathrm{mg} / \mathrm{kg}$, (C5) hyperlipidemics diet + aqueous extract $54.68 \mathrm{mg} / \mathrm{kg}$ ). (Magnification: 400×). 

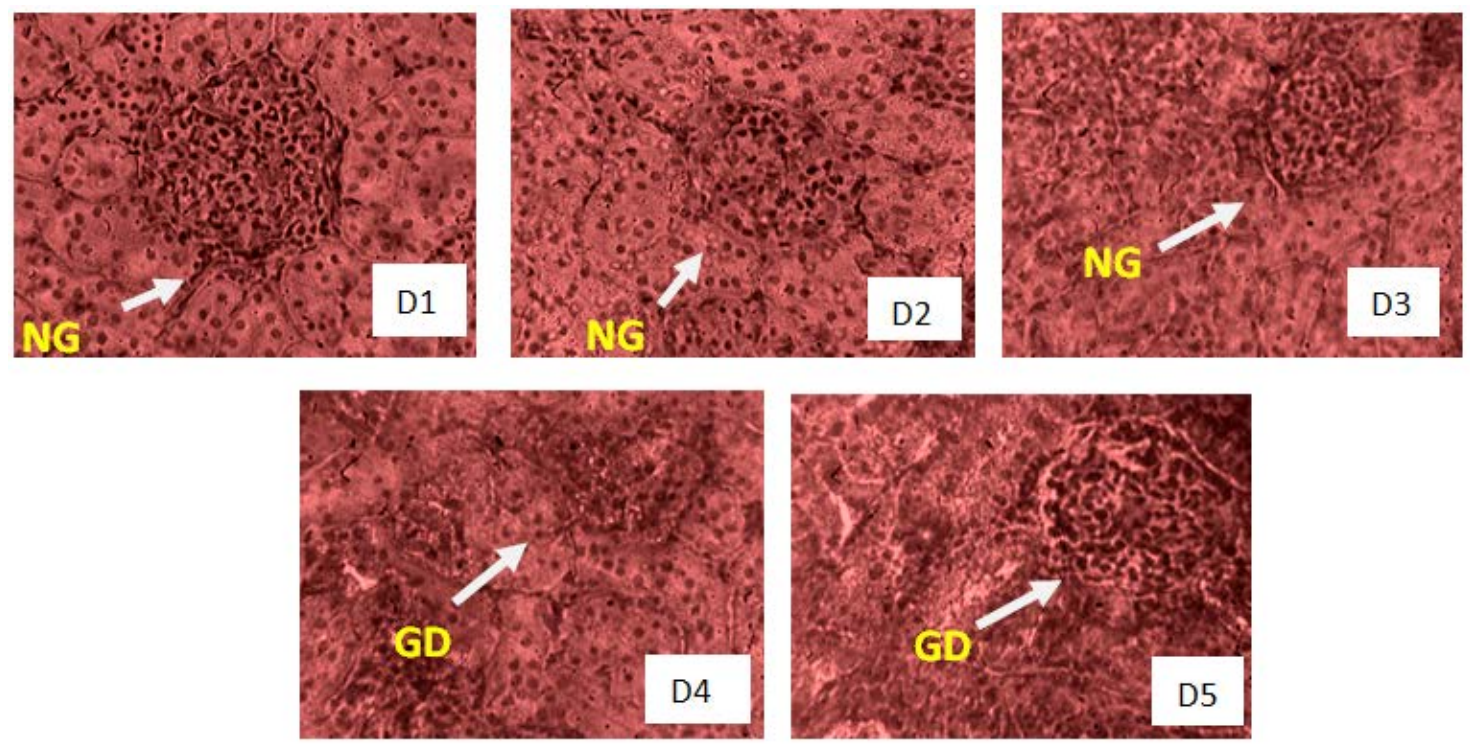

Figure 4. Histological section of kidneys of rats of hypolipidemic test: (D1): normal control, (D2): normal diet + Atorvastatine, (D3): normal diet, (D4): normal diet + aqueous extract $3.41 \mathrm{mg} / \mathrm{kg}$; (D5): normal diet + aqueous extract $13.67 \mathrm{mg} / \mathrm{kg}$. NG: normal glomerular, GD: glomerular destruction (Magnification: 400×).
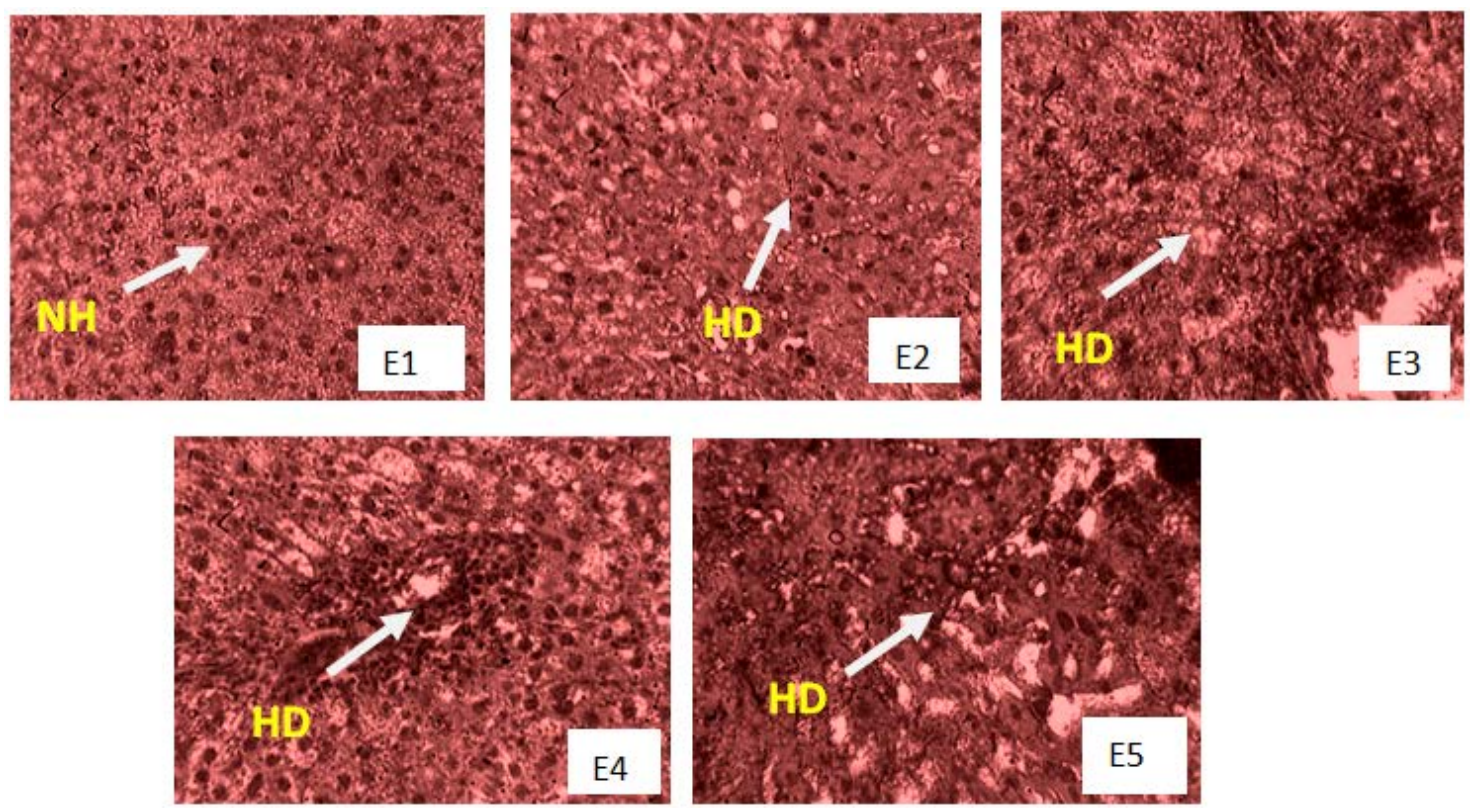

Figure 5. Histological section of livers of rats of hypolipidemic test: (E1) normal control, (E2) normal diet + Atorvastatine, (E3) normal diet, (E4) normal diet + aqueous extract $3.41 \mathrm{mg} / \mathrm{kg}$; (E5) normal diet + aqueous extract $13.67 \mathrm{mg} / \mathrm{kg}$. NH: normal hepatocyte, HD: hepatocyte degenerative. (Magnification: $400 \times)$. 

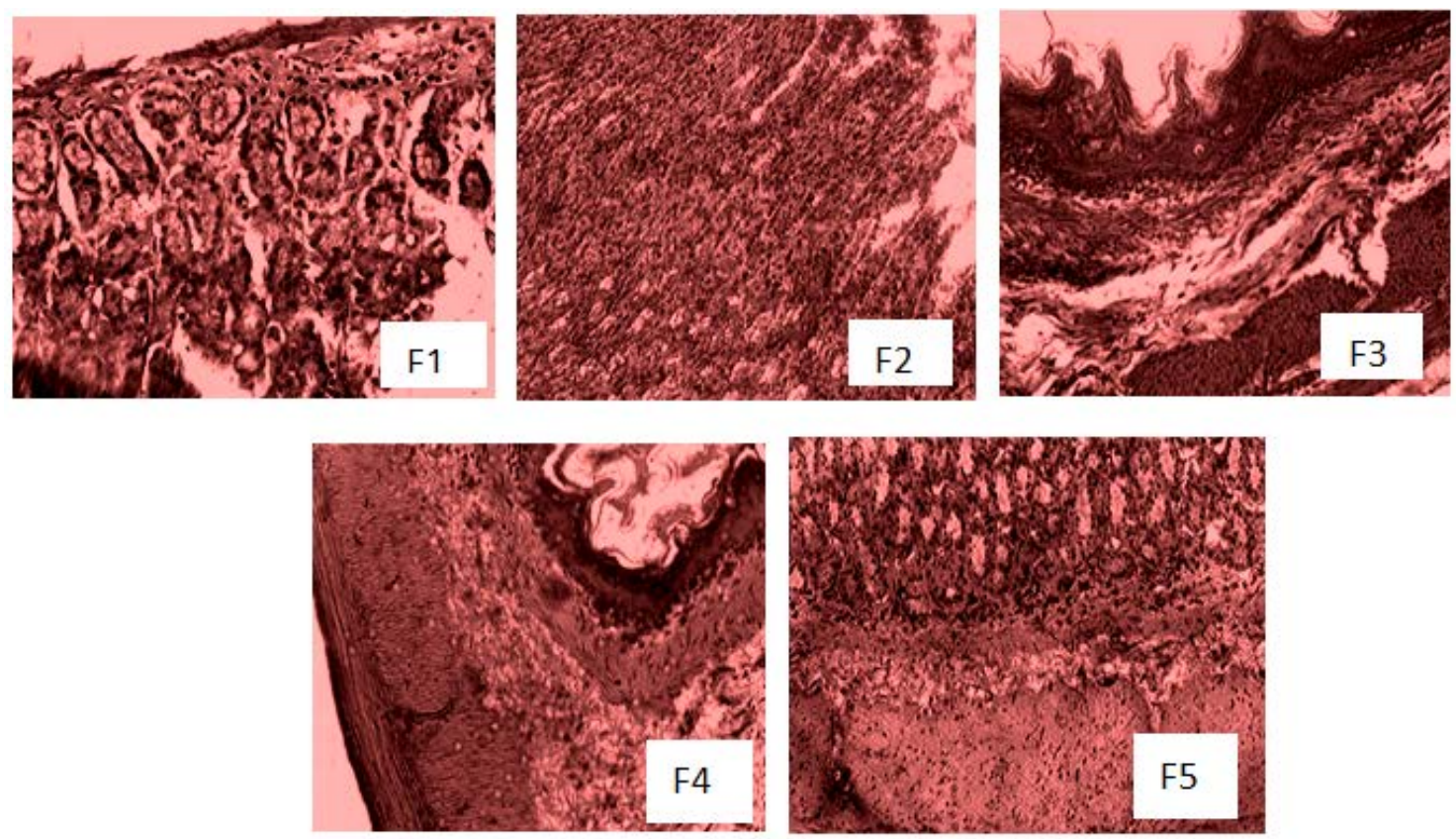

Figure 6. Histological section of stomachs of rats of hypolipidemic test: (F1): normal control, (F2): normal diet + Atorvastatine, (F3): normal diet, (F4): normal diet + aqueous extract $3.41 \mathrm{mg} / \mathrm{kg}$; (F5): normal diet + aqueous extract $13.67 \mathrm{mg} / \mathrm{kg}$. (Magnification: $400 \times$ ).

\section{Discussion}

Hyperlipidemia is a major contributor of cardiovascular pathogenesis which is a leading health problem in the world (Mahley and Bersot, 2006; Kumar et al., 2008), therefore prime consideration in the therapy of hyperlipidemia and arteriosclerosis is to attenuate the elevated blood levels of lipids. Results of the chemical analysis of $T$. leontopetaloides extract showed the presence of polyphenols, alkaloid and saponins. Several studies have demonstrated the beneficial effects of polyphenols (Juźwiak et al., 2005; Andreadou et al., 2006) and saponins (Francis et al., 2002; Astuti et al., 2009; Afrose et al., 2010) on the reduction of cholesterol. In this study the rats fed with high fat diet associated with aqueous tubers extract loss the weight and rats receiving high fat diet only gained the weight. Since food intake is low in rats treated with extracts, the weight loss could be due to the effect of aqueous tuber extract which would reduce appetite. The inhibition of intestinal lipase and absorption of fatty acid by polyphenols could also induce loss of weight as explain by Ransac et al. (1991) on their study.

Administration of aqueous tuber extract with high fat diet during 21 days, significantly and successfully prevented the elevation of serum total cholesterol, triglyceride, low density lipoproteins cholesterol, very low density lipoproteins and prevent the decrease of high density lipoproteins in rats. Reduction of lipids blood levels observed could be explained by saponins, polyphenols and alkaloids containing in extract. In fact, saponins, polyphenols and alkaloids could form complex with cholesterol and bile acids and cause theirs excretion in feces (Oakenfull and Hood, 1979). Creatinin levels showed no changed in the group fed with HFD + aqueous tuber extract, but it is increased in negative control group which fed with HFD only. These results show that aqueous tuber extract protect the kidneys, but high fat diet affected the kidneys, it was confirm by histological of kidneys (Figure 1, A2) which showed a destruction of glomerules. High levels of creatinin indicated that the 
kidneys have an abnormality. According to James et al. (2010) creatinin is a waste product that results from creatin metabolism in muscle, and its retention in the blood is evidence of kidneys impairment. The activities of alanine amino transferase and aspartate amino transferase are two excellent markers of the liver damage increased significantly when aqueous tuber extract was associated with hight fat diet. This confirms the hepatocyte degeneration observed in the rats fed with HFD + aqueous tuber extract (Figure 2, B4, B5).

In hypolipidemic test, the aqueous extract of tuber administered in hyperlipidemic rats after the change of diet caused a significant decrease in the serum level of triglyceride, cholesterol, LDL and increase of the serum level of HDLcholesterol with the two doses $(3.41 \mathrm{mg} / \mathrm{kg}$, $13.67 \mathrm{mg} / \mathrm{kg}$ ). Hypotriglyceridemic observed effect might be due to a decrease in the fatty acid synthesis (Bopanna et al., 1997) and inhibition of tissues lipases (Khanna et al., 2002). The mechanism involve in lowering of cholesterol might be related to the suppression of cholesterol biosynthesis by decrease in the HMG-CoA reductase activity which is the rate-limiting enzyme in the cholesterol biosynthetic pathway (Glässer et al., 2002). The abdominal fat to body weight ratio of the treated rats was decreased, this explains that the aqueous tuber extract which contents saponins, alkaloid and polyphenols could limited fat deposit in the tissues and cells (Sodipo et al., 2009; Rodda and al., 2011). The higher increased observed with the stomach and the decreased of testis to body ratio in the treated rats, demonstrated that aqueous tuber extract could affect stomach and testis by saponins that it content. According to Caddick et al. (2002) saponins have are able to cause lesion of hepatocytes and gastric cells. The no better organized of the cyto-architecture of the kidneys, liver parenchyma and normal organization of the stomach of rats received the two doses of extract $(3.41 \mathrm{mg} / \mathrm{kg}, \quad 13.67 \mathrm{mg} / \mathrm{kg})$ in hypolipidemic test may be due to the by bioactive molecules of the tuber of T. leontopetaloides. This explain that administration of aqueous tuber extract of $T$. leontopetaloides after dietary changed did not provides any protective role to the liver which is the first organ susceptible to any injurious substances in cases in toxicity.

\section{Conclusion}

Results obtained from the present study indicate that aqueous tuber extract of T. leontopetaloides has significant antihyperlipidemic and hypolipidemic activities. These effects are probably due to its bioactive substances. Thus, the composition of bioactive substances should be well study and the toxicity of the extract of these tubers needs to be investigated.

\section{Acknowledgements}

The authors acknowledge the technical assistance of the laboratory staff from the Department of Food Science and Nutrition of National School of Agro-Industrial Sciences of Ngaoundere University and from Department of Biological Sciences of Faculty of Sciences of Ngaoundere University.

\section{Conflict of interests}

The authors declare that there are no conflicts of interest.

\section{References}

Adom, K. K.; Sorrels, M. E.; Liu, R. H. Phytochemical profiles and antioxidant activity of wheat varieties. J. Agric. Food. Chem., v. 51, No. 26, p. 7825-7834, 2003. https://dx.doi.org/10.1021/jf030404l

Afrose, S.; Hossain, M. S; Tsujii, H. Effect of karaya saponin on serum and egg yolk cholesterol in laying hens. Br. Poult. Sci., v. 51, No. 6, $\quad$ p. 797-804, 2010. https://dx.doi.org/10.1080/00071668.2010.526924

Andreadou, I.; Iliodromitis, E. K.; Mikros, E.; Constantinou, M.; Agalias, A.; Magiatis, P.; Skaltsounis, A. L.; Kamber, E.; TsantiliKakoulidou, A.; Kremastinos, D. T. The olive constituent oleuropein exhibits anti-ischemic, antioxidative, and hypolipidemic effects in 
anesthetized rabbits. J. Nutr., v. 136, No. 8, p. 2213-2222, 2006.

Astuti, D. A.; Wina, E.; Haryanto, B.; Suharti, S. Performa dan Profil Beberapa Komponen Darah Sapi Peranakan Ongole yang Diberi Pakan Mengandung Lerak (Sapindus rarak De Candole). Media Peternakan, v. 32, No. 1, p. 63-70, 2009. Available from: $<$ http://medpet.journal.ipb.ac.id/index.php/medi apeternakan/article/view/1159/318>. Accessed on: Nov. 23, 2016.

Ballantyne, C. M. Treatment of dyslipidemia to reduce cardiovascular risk in patients with multiple risk factors. Clin. Cornerstone, v. 8, suppl. 6, p. S06-S13, 2007.

Bopanna, K. N.; Kannan, J.; Sushma, G.; Balaraman, R.; Rathore, S. P. Antidiabetic and antihyperglycemic of neenm seed kernel powder on alloxan diabetic rabbits. Ind. J. Pharmacol., v. 29, No. 3, p. 162-167, 1997.

Bourely, J. Observation sur le dosage de l'huile des graines de cotonnier. Coton et Fibres Tropicales, v. 27, No. 2, p. 183-196, 1982.

Caddick, L. R.; Wilkin, P.; Rudall, P. J.; Hedderson, T. A. J; Chase, M. W. Yams reclassified: a recircumscription of Dioscoreaceae and Dioscoreales. Taxon, v. 51, No. 1, p. 103-114, 2002. http://dx.doi.org/10.2307/1554967

Francis, G.; Kerem, Z.; Makkar, H. P.; Becker, $\mathrm{K}$. The biological action of saponins in animal systems: a review. Br. J. Nutr., v. 88, No. 6, p. 587-605, https://dx.doi.org/10.1079/BJN2002725

Friedewald, W. T.; Levy, R. I.; Friedrickson, D. S. Determination of LDL cholesterol. In: Tietz, N. W. (Ed.). Textbook of Clinical Biochemistry. Washington, DC: AACC Press, 1972. p. 874-898.

Garine, I. Nourriture de brousse chez les Muzey et les Masa du Nord Cameroun. In: Raimond, C. Colloque International Méga-Tchad: Ressources Vivrières et Choix Alimentaires dans le Bassin du Lac Tchad, 2002.

Glässer, G.; Graefe, E. U.; Struck, F.; Veit, M.; Gebhardt, R. Comparison of antioxidative capacities and inhibitory effects on cholesterol biosynthesis of quercetin and potential metabolites. Phytomedicine, v. 9, no.1, p. 3340, 2002. https://dx.doi.org/10.1078/0944-711300080

Glick, M. R.; Ryder, K. W.; Jackson, S. A. Graphical comparisons of interferences in clinical chemistry instrumentation. Clin. Chem., v. 32, No. 3, p. 470-475, 1986.
Available from: <http:/clinchem.aaccjnls.org/ content/clinchem/32/3/470.full.pdf $>$. Accessed on: Nov. 23, 2016.

Hamlat, N.; Neggazi, S.; Benazzoug, Y.; Kacimi, G.; Chaïb, S.; Aouichat-Bouguerra, S. Regime hyperlipidique et processus atherosclérose chez Rattus norvegecus. Science \& Technologie C, No. 27, p. 49-56, 2008.

Harborne, J. B. Phytochemical methods. London, UK: Chapman Hall, 1991.

Henry, R. J. Clinical chemistry: principles and technics. 2. ed. New York: Harper and Row, 1974.

Hiai, S.; Oura, H.; Nakajima, T. Color reaction of some sapogenins and saponins with vanillin and sulphuric acid. Planta Medica, v. 29, p. 116-122, 1976. https://dx.doi.org/10.1055/s0028-1097639

James, D. B.; Elebo, N.; Sanusi, A. M.; Odoemene, L. Some biochemical effect intraperitoneal administration of Phyllanthus amarus aqueous extracts on normal glycemic albinos rats. Asian. J. Med. Sci., v. 2, No. 1, p. 7-10, 2010. Available from: $<$ http://maxwellsci.com/print/ajms/v2-710.pdf $>$. Accessed on: Nov. 23, 2016.

Juźwiak, S.; Wójcicki, J.; Mokrzycki, K.; Marchlewicz, M.; Białecka, M.; WendaRózewicka, L.; Gawrońska-Szklarz, B.; Droździk, M. Effect of quercetin on experimental hyperlipidemia and atherosclerosis in rabbits. Pharmacological Reports, v. 34, p. 604-609, 2005. Available from: <http://www.if-pan.krakow.pl/pjp/pdf/2005/ 5_604.pdf $>$. Accessed on: Nov. 23, 2016.

Kay, D. E. Crops and product digest. 2. ed. London: Tropical Development and Research Institute, 1987. (No. 2, Root Crops).

Khanna, A. K; Rizvi, F; Chander, R. Lipid lowering activity of Phyllanthus niruri in hyperlipemic rats. J. Ethnopharmacol., v. 82, No. 1, p. 19-22, 2002. http://dx.doi.org/10.1016/S0378-8741(02)00136-8

Kumar, S. A.; Avijit, M.; Saravanan, V. S. Antihyperlipidemic activity of Camellia sinensis leaves in Triton WR-1339 induced albino rats. Pharmacognosy Mag., v. 4, No. 13, p. 60-64, 2008.

Mahley, R. W.; Bersot, T. P. Drug therapy for hypercholesterolemia and dyslipidemia. In: Brunton, L. L. (Ed.). Goodman and Gillman's the pharmacological basis of therapeutics. 11. ed. New York: McGraw Hill, 2006. p. 933-966.

Makkar, H. P. S.; Blummel, M.; Borowy, N. K.; Becker, K. Gravimetric determination of tannins 
and their correlations with chemical and protein precipitation methods. J. Sci. Food. Agric., v. 61, No. 2, p. 161-165, 1993. https://dx.doi.org/10.1002/jsfa.2740610205

Ndouyang, C. J.; Ejoh, A. R.; Bakar, A.; Facho, B.; Njintang, Y. N.; Mohammadou, B. A.; Mbofung, C. M. Propriétés physico-chimiques et fonctionnelles de Tacca leontopetaloides (L.) Kuntze, tubercule non conventionnel. e-Revue de Génie Industriel., No. 3, p. 34-45, 2009. Available from: <http://www.revue-genieindustriel.info/document.php?id=804>.

Accessed on: Nov. 23, 2016.

Oakenfull, D. G.; Fenwick, D. E.; Hood, R. L. Effects of saponins on bile acids and plasma lipids in rats. Br. J. Nutr., v. 42, p. 206-216, 1979. Available from: $<$ https://www.cambridge.org/core/services/aopcambridge-core/content/view/

S0007114579000283>. Accessed on: Nov. 23, 2016.

Ransac, S.; Gargouri, Y.; Moreau, H.; Verger, R. Inactivation of pancreatic and gastric lipases by tetrahydrolipstatin and alkyl-dithio-5-(2nitrobenzoic acid). Eur. J. Biochem., v. 202, No. 2, p. 395-400, 1991. http://dx.doi.org/10.1111/j.14321033.1991.tb16387.x

Reitman, S.; Frankel, S. A colorimetric method for the determination of serum glutamic oxaloacetic acid and glutamic pyruvic transaminases. Am. J. Clin. Pathol., v. 28, p. 56-67, 1957.
Reynolds, K.; Chin, A.; Lees, K. A.; Nguyen, A.; Bujnowski, D.; He, J. A meta-analysis of the effect of soy protein supplementation on serum lipids. Am. J. Cardiol., v. 98, p. 633-640, 2006. https://dx.doi.org/10.1016/j.amjcard.2006.03.042

Richmond, W. Medical analysis. Clin. Chem., v. 19, p. 1350, 1973.

Raghuveer, R.; Sreeja, K.; Sindhuri, T.; Kumar, A. K. Antihyperlipidemic effect of Tagetes erecta in cholesterol fed hyperlipidemic rat. Der. Pharmacia Lettre, v. 3, p. 266-270, 2011. Available from: $<$ http://www.scholarsresearchlibrary.com/article s/antihyperlipidemic-effect-of-tagetes-erecta-incholesterol-fedhyperlipidemic-rats.pdf $>$.

Accessed on: Nov. 23, 2016.

Saghir, M. R.; Sadiq, S.; Nayak, S.; Tahir, M. U. Hypolipidemic effect of aqueous extract of Carum carvi (Black Zeera) seeds in diet induced hyperlipidemic rats. Pak. J. Pharm. Sci., v. 25, No. 2, p. 333-337, 2012.

Sodipo, O. A.; Abdulrahman, F. I; Sandabe, U. K, Akinniyi, J. A. Total lipids profile with aqueous fruit extract of Solanum macrocarpum Linn in rats. J. Pharm. Biores., v. 6, No. 1, p. 10-15, 2009.

Suresh, Y.; Das, U. N. Protective action of arachnidonic acid against alloxan induced cytotoxicity and diabetes mellitus. Prostaglandins Leukot. Essent. Fatty Acids, $\begin{array}{lll}\text { v. 64, } & \text { No. } 1, \quad \text { p. 37-49, } 2001 .\end{array}$ https://dx.doi.org/10.1054/plef.2000.0236

License information: This is an open-access article distributed under the terms of the Creative Commons Attribution License, which permits unrestricted use, distribution, and reproduction in any medium, provided the original work is properly cited. 